SOCIAL RESEARCH REPORTS

ISSN: 2066-6861 (print), ISSN: 2067-5941 (electronic)

\title{
THE FAMILY BACKGROUND - A THEORETICAL APPROACH TO THE FACTORS OF THE CHILD'S SCHOOL SUCCESS
}

\author{
Mihaela RUS
}

Social Research Reports, 2021, Vol. 13, Issue 1, pp. 30-37

The online version of this article can be found at:

www. researchreports.ro

\section{https://doi.org/10.33788/srr13.1.3}

Published by:

Expert Projects Publishing House

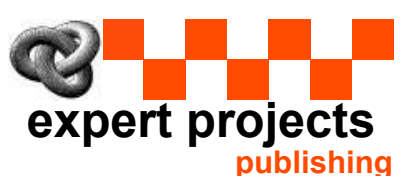

Covered by Index Copernicus International

www.indexcopernicus.com

Directory of Open Access Journals

www.doaj.org

On behalf of:

Center for Program and Social Development

Aditional services and information about Social Research Reports can be found at:

www.researchreports.ro 


\title{
THE FAMILY BACKGROUND \\ - A THEORETICAL APPROACH \\ TO THE FACTORS OF THE CHILD'S SCHOOL SUCCESS
}

\author{
Mihaela RUS ${ }^{1}$
}

\begin{abstract}
The objective of the study is to approach from a theoretical point of view the importance of the family in the school-family-student triad. The article will focus on the analysis of the role that the family has in the instructive-educational process of the child, focusing on the specialized literature in the field. School and family are the main factors that complete the education of the individual. Each of them contributes through their specific influences to the formation and social integration of the child. The family environment and the school environment are two dimensions of children's lives that make their mark on the formation of their personality. Systematic school education, however, can prove to be ineffective if the family is not involved in carrying out the instructive-educational tasks in the parent-child relationship. Families have decisive educational potential, especially in the first years of a child's life, and strengthen the educational efforts exercised by the school. Thus, working together in interdependence, through combined actions and giving the student an active role in his development, the premises are created for achieving the school success expected by all educational actors: family, school, and student.
\end{abstract}

Keywords: social background, family background, school, education, school success, culture

\section{Introduction}

Lately we observe, in all countries of the world, regardless of their degree of development, an increased interest in evaluating schools from the perspective of school results obtained by students. This process must be based on school success, student progress, the sum of social and cultural factors. School success is determined by the existence of many protective factors at different systemic levels: family, neighbourhood, friends, teachers involved in the instructionaleducational process, culture and values of the school. Moreover, school success is threatened by a number of risk factors. The internal resources of the students,

\footnotetext{
${ }^{1}$ Departement of Sociology and Social Work, "Alexandru Ioan Cuza" University from Iasi,
} ROMANIA. E-mail: mihaela30rus@yahoo.com 
another determining factor of the school success, but also the factors of the social context have a high weight in obtaining the school results (Sălăvăstru, 2004; Țoc, 2016).

Since ancient times, the family and its problems have been a central objective of reflection and analysis because it is the fundamental group unit of society. For more than a century, the family has been capturing the attention of many scientific disciplines: legal, economic, demographic, psychological, etc., between the various branches of these sciences operating numerous interferences and overlaps. The family and the school consciously pursue the same educational goal, in addition to the physical development of the individual, to form a cultural horizon, to teach him to think, to form work skills and to endow him with rules of correct behaviour in society (Rus, Radu, 2014).

\section{Family - current definitions and approaches}

The definition of the family and the perception of it have simultaneously evolved with the society. Thus, Levi-Strauss (2011) sees the family as a group that has its origins in marriage, consisting of husband, wife and a number of children born in this union, which are united by rights and obligations of various factors (moral, legal, religious, economic, social ones). Defining the family, Burgess \& Locke (1971) focuses on personal interactions and intercommunication, including the roles of family members, and Mahler \& Bergman (1975) outlines the same social group, achieved through marriage, including people living together, engaging in activities domestic and are united by biological, psychological, moral and legal relationships. For Popescu-Neveanu (1978), the family is a social institution based on the mutual choice of marital partners, with the function of ensuring the reproduction of the species in certain sociocultural conditions. At the beginning of the 21st century, Jinga \& Negret (1999) outlines economic, social and religious factors that have as an effect the "family crisis" and cites specialists who believe that in the not-too-distant future there will be a dissolution of this institution.

In contemporary societies, a family have undergone profound transformations, so that the term "family" has become increasingly ambiguous and covers realities different from those which are characteristic of previous generations. Today, specialists discuss, firstly, who or what constitutes a family and only secondly, which of the interpersonal relationships can be described as family and which are not, which are normal, moral and which are deviant, which of them would they must be supported and promoted by the state and which should not (Jinga \& Negreț, 1999; Cojocaru, 2008).

"The postmodern family is not a new model of family life, it is not the next stage in the orderly progression of family history, but the stage in which the belief in a logical progression of stages disappears. Breaking the gradual patterns of family history and incorporating both experimental and nostalgic elements, the postmodern family gropes forward or backward in an uncertain future." (Stacey, 1990, 17-18). In the context of the definition elaborated by Stacey, J. the individual 
interest towards the family relations decreases in the contemporary society, as an effect of the diminution of the productive work from the domestic environment.

\section{Family factors in forming the favourable context for the child's education}

During the development of human society, the family became responsible for the upbringing and education of children in the following aspects: maintaining the biological continuity of the individual and society (through procreation, training and education of children); maintaining the cultural identity by transmitting the cultural heritage in the process of socialization; satisfying emotional needs, intimate feelings, ensuring a sense of security and maintaining personality; the social integration of its members through the processes of orientation, education and socialization (Voinea, 1996; Mihăilescu, 1999; Ilut, 2005; Fraser, 2000).

Thus, the functions that the family fulfils in the life of its members were specified and differentiated: the economic and the biological functions, to support through emotional comfort, the interpersonal and cultural communication support to transmit social and educational values - to raise and train the young generation, the socialization function - which implies the gradual induction of social norms and values (Voinea, 1996; Voinea, 2005; Vrășmaș, 2002).

In the debates regarding the factors that determine the school success, it is generally accepted the explanation according to which the family background represents one of the main determinants, because it constitutes the first social environment in which the development takes place. There is a positive relationship between the two notions. Students who come from advantageous social backgrounds and who are placed in a higher position in the hierarchical structure of a society determined by the access and control of valuable resources in a society, are more likely to be successful in school, compared to those placed in lower positions in a social stratification scheme. The background is a concept used in quantitative studies that include those aspects that are considered relevant for defining the characteristics of an individual occupying a position in the social structure. Such variables can be: income, occupation, educational level, family possessions, family structure, environment of residence, religion, migration (Stahl, 2002; Brese \& Mirazchiyski, 2013). However, the most commonly used are those aimed at the economic status of individuals, which is composed of variables such as education, income and occupation.

Current international research in the field of family sociology highlights two directions of approaching children's academic success as a result of family involvement in their education: a first approach involves parents competing for high quality educational opportunities for their children, these better educational opportunities leading implicitly to better academic performance; a second approach concerns how parents' behaviour, as well as educational support for their children, could cultivate children's learning habits and influence academic performance ( $\mathrm{Li}$ et al., 2018). 
In the results of the study conducted in China by Li et al (2018), it could be identified that at the family level, the family education is very important for children's academic performance. Parents with lower socioeconomic status can cultivate good children's learning behaviour through their own educational participation (this involves the care and supervision of their children's study and active communication with teachers). The active participation of parents in the educational training of their children can in fact lead to the improvement of children's academic performance. Moreover, the active participation of parents is a factor that reduces the impact of the socio-economic status of the family on the children's academic achievements. (Li et al, 2018). The implications at the school level are observed when schools provide sufficient services and resources, which contribute to the improvement of students' academic results. The school thus contributes by improving the knowledge and teaching skills of teachers and by communicating with parents, creating and facilitating a positive educational atmosphere at school and at home. This new context created through school-family collaboration increases children's interest in learning and cultivates children's good learning habits (Li et al., 2018).

The results of the study conducted by Li et al. (2018) are similar to the approach of Lyu et al. (2019), from a study that analyses the relative importance of the family environment to structural factors in determining children's academic achievements in three different societies: China, the United States and Germany. In the theoretical substantiation of the study, Lyu et al. (2019) appeals to the differences generated by the inequity of educational and social services. In addition to the influence of macroeconomics on the inequity of distribution of social and educational services, globally, in the context of education, the socioeconomic status of the family brings strong influences on the educational level of an individual. (Blau \& Duncan, 1967; Lyu et al., 2019). The influences of the socioeconomic status of the family are manifested in two directions: in the first instance, the economic position of a family determines how much parents can invest in the education and development of their children (Kaushal et al., 2011; Lyu et al., 2019); second, middle-class parents are more likely than working-class parents to engage in parenting practices conducive to children's educational achievement (Lareau, 2011; Mayer, 1997; Lyu et al., 2019).

Last but not least, the family structure, the educational resources that the family can make available to children, as well as the advantages related to the forms of cultural and social capital existing in the family have been frequently used to operationally define the family background (Stănciulescu, 1996; Alexandrescu, 2006; Brese \& Mirazchiyski, 2013). The same authors, starting from an analysis of the theoretical relevance and their use in the empirical researches of education, conclude what is the logic for which the previously mentioned aspects can be included in the definition of the concept of family environment of origin. The precarious, unstable economic situation, the low level of family income influences the child's academic evolution. It can be seen that, especially in rural areas, poverty makes it impossible for many families to bear the child's schooling expenses related to transport, school supplies, clothing, which has the effect of interrupting schooling, dropping out of school before the end of compulsory schooling (Stahl, 2002; Sălăvăstru, 2004; Țoc, 2016). 
From another point of view, the low level of income forces some families to make great financial efforts, sacrifices to support the education of children, which has the effect of domestic conflicts, strained relationships, the accumulation of frustrations related to family poverty, all together negatively influencing the child's school results (Bernstein, 1979; Hatos, 2006).

Children from poor families are less likely to have a long school career. The expenses that this entails, determine that many families to be oriented towards shorter school courses and professions that are immediately demanded on the labour market.

The level of income is often correlated with the environment of residence, being probable the concentration in certain areas of some individuals with similar economic characteristics. This increases the possibility that in a school there are similar children enrolled in terms of parental income. A high degree of safety in school and in the area where students live has a positive effect on their school success (Bronfenbrenner, 1979; Stahl, 2002). According to this theory, violence in the microsystems in which young people live (school, neighbourhood) are risks that, on the one hand, endanger their physical and emotional safety, and on the other hand reduce their quality and access to potential training opportunities within the school and the community.

In the literature there are authors who argue that school success depends more on cultural factors or the level of education of parents than on material living conditions (Jigău, 1998; Levi-Strauss, 2011; Gherasim \& Butnaru, 2013). In this approach, the level of parents' aspirations and the attitude they have towards education are invoked (Gray, 2004), but especially the cultural baggage itself: the language used in the family, its cultural practices (watching cultural shows, visiting of museums, exhibitions, reading, etc.) and in the value system. The student who comes from such families will benefit during schooling from a cultural capital identical or close to the culture promoted by the school, which will facilitate his school success (Sălăvăstru, 2004; Hatos, 2006). The professional status can be considered an indicator that can suggest the level of income of an individual, but also the prestige associated with it in a society (Stacey, 1990). The educational level is another important variable because it is an institutionalized form of cultural capital, but also because the educational practices of parents with a high level of education are closer to the practices of the education system (starting with the practices by which parents educate their children and continuing with the learning environment at home, in which they socialize). From this point of view, the family represents the agent of the primary pedagogical action that fixes the primary classroom behaviour, the first perception, thinking and action schemes that will function as a foundation and principle of selection in the process of incorporating all subsequent experiences. The individual integrates in the unit of a systematic biography that is organized starting from the original social class situation, experienced in a determining type of family structure (Stănciulescu, 1996). 
Family property is also an appropriate indicator, as it is considered representative of either material well-being or the existence of educational resources, which can be considered the result of the type of education that individuals have acquired and of the income / the assets they own (Jigău, 1998, Mihăilescu, 1999; Vrăşmaş, 2002).

In modern societies, primary behaviour orients school options and orientation by adjusting subjective hopes to objective chances of success, specific to the social class, and thus determining the self-selection of candidates for a form of education (Stănciulescu, 1996; Brese \& Mirazchiyski, 2013).

The pedagogical action of the family imprints a class ethos as one of the components of the incorporated cultural capital (Bernstein, 1979; Alexandrescu, 2006; Hatos, 2006), inscribing in the subjective structures the categories (kindness, honesty, order, balance, seriousness, diligence, culture, creativity, etc.) according to which the child will self-classify and be classified, first in school structures, and later in social ones, occupying the "position that belongs to him" from his point of view and from the point of view of those around.

Gherasim \& Butnaru (2013) identify parenting practices that positively influence the evolution of children to achieve school success, these being one of the most important resources in this regard. Thus, school performance involves parents who are supportive and involved in their children's education, cultivating independence in decision-making, encouraging learning behaviour and parental control. The authors also specify that the receptivity of parents to the needs of the child, active involvement in school and extracurricular activities of the child exerts positive influences in terms of school adaptation. Last but not least, an important role in obtaining meritorious school results is played by the emotional climate and positive parent-child communication factors that have a strong impact in forming the child's perception of their own skills (Bernstein, 1979; Voinea; 1996; Sălăvăstru, 2004).

\section{Conclusion}

We consider that we have managed to highlight the family factors that underlie the achievement of school success. We also specify that not only these factors are necessary and sufficient for the student's success, the latter being a cumulating of several favourable conditions. Therefore, the child's belonging to a favoured environment from a socio-economic and cultural point of view does not have as a guaranteed effect the achievement of school success and, later, the socio-professional success. This membership is just one factor that can positively influence school success in a given context. In conclusion, the contents instilled by the education offered by the family, the personal qualities of the child, a high level of aspiration, a healthy and supportive educational climate are particularly sustainable and are the starting point for the contents of school education, prerequisite for school success. 


\section{References}

Alexandrescu, P. (2006). Rolul școlii și al familiei în educaţia tinerei generații în orizontul integrării europene. Revista Română de Sociologie. XVII (3-4), 361-381.

Bernstein, P. (1979). Studii de sociologie a educației. București: Editura Didactică și Pedagogică.

Blau, P.M., Duncan, O.D. (1967) The American Occupational Structure, New York: John Wiley and Sons.

Brese, F., Mirazchiyski, P. (2013). Measuring Students' Family Background in Large-scale Education Studies. IEA International Research Conference July 1-3, Gothenburg, Sweden.

Bronfenbrenner, U. (1979). The ecology of human development: Experiments by nature and design. Cambridge: Harvard University Press.

Burgess, E.W., \& Locke, H.J. (1971). The family. New York: Van Nostrand Reinhold

Cojocaru, D. (2008). Copilaria si constructia parentalitatii. Asistenta maternala in Romania. Iași: Polirom.

Fraser, M.W. (2004). Intervention Research in Social Work: Recent Advances and Continuing Challenges. Research on Social Work Practice, 14(3), 210-222. DOI: $10.1177 / 1049731503262150$.

Gherasim, L.R., \& Butnaru, S. (2013). Performanța școlară. Determinanți individuali și contextuali în adolescență. Iași: Editura Polirom.

Gray, J. (2004). Frames of reference and traditions of interpretation: some issues in the identification of 'under-achieving' schools. British Journal of Educational Studies, 52(3), 293-309. DOI: 10.1111/j.1467-8527.2004.00269.x.

Hatos, A. (2006). Sociologia educației. Iași: Editura Polirom.

Iluț, P. (2005). Sociopsihologia și antropologia familiei. Iași: Polirom.

Jigău, M. (1998). Factorii reușitei școlare. București: Grafoart.

Jinga, I., \& Negreț, I. (1999). Familia, acest miracol înșelător. București: Editura Didactică şi Pedagogică.

Kaushal, N., Magnuson, K., \& Waldfogel, J. (2011). How is family income related to investments in children's learning? In G. J. Duncan, R. J. Murnane (eds). Whither Opportunity? Rising Inequality, Schools, and Children's Life Chances. New York: Russell Sage Foundation (pp. 187-205).

Lareau, A. (2011). Unequal Childhoods: Race, Class and Family Life. Berkeley: University of California Press.

Levi-Strauss, C.1. (2011). Antropologia şi problemele lumii moderne. Iaşi: Polirom

Li, Z., \& Qiu, Z. (2018). How does family background affect children's educational achievement? Evidence from Contemporary China. The Journal of Chinese Sociology, 5,13. DOI: 10.1186/s40711-018-0083-8.

Lyu, M., Li, W., \& Xie, Y. (2019). The influences of family background and structural factors on children's academic performances: A cross-country comparative study. Chinese Journal of Sociology, 5(2), 173-192. DOI: 10.1177/2057150X19837908.

Mahler, M.F., \& Bergman, A. (1975). The psychological birth of the human infant. New York: Basic Books.

Mayer, S.E. (1997). What money can't buy: family income and children's life chances. Cambridge, MA: Harvard University Press. 
Mihăilescu, I. (2005). Familia în societățile europene. București: Editura Universităţii București.

Popescu-Neveanu, P. (1978). Dicționar de psihologie. București: Albatros.

Rus, C.M., \& Radu L.E. (2014). The Implication of Physical Education and Sport in the Moral Education of High School Students. Revista de Cercetare si Interventie Sociala, 45, 45-55.

Sălăvăstru, D. (2004). Psihologia educației. Iași: Polirom.

Stacey, J. (1990). Brave new families. New York: Basic Books.

Stahl, P. H. (2002). Familia și școala. Contribuții la sociologia educației. București: Paidea Stănciulescu, E. (1996). Teorii sociologice ale educației. Iași: Editura Polirom.

Țoc, S. (2016). Familie, școală și succes școlar în învățământul liceal românesc. Calitatea vieții. XXVII (3):189-215.

Voinea, M. (1996). Psihosociologia familiei. București: Editura Universității București; 1996.

Voinea, M. (2005). Familia contemporană. Mică enciclopedie. București: Editura Focus. Vrășmaș, E. A. (2002). Consilierea și educația părinților. București: Aramis. 